\title{
New social phenomena in the optics of values in post-communist Albania
}

\author{
Ina K. Zhupa \\ Phd Candidate \\ Professor at the Social Science Faculty, \\ European University of Tirana
}

\begin{abstract}
Albanian society is experiencing post-communist period, which is associated with numerous changes in the social, economic and political field. Important aspect, are the values that people believe and reflect on their daily behavior. Values change as a result of other changes, especially economic ones, but not so fast and immediate like in other areas. Inglehart explains that the change of values is a result of greater economic development, an economic development in a society influence to fulfill the basic requirements that people have to live, and in this way they have the tendency to require for another value orientation. (Inglehart,Baker,2000). In this regard, we try to look how the people in Albania, as a former closed communist society, might judge on certain social phenomenons that are difficult to be accepted and welcomed. Phenomena, such as divorce, abortion, euthanasia, suicide, prostitution, homosexuality, that are already common for a democratic society. Based on a quantitative methodology, surveys have been conducted to look at people's perceptions about these phenomena. These data are analyzed in this paper and bring us a society with traditional values. Analysis of these data will help us to understand better what kind of values we share in relation to the conception of this social phenomenon in albanian society, the problems that we can face and some predictions for the future.
\end{abstract}

Keywords: cultural change, social behavior, social phenomena, value patterns, cultural democratization.

\section{Introduction}

Albania, as a country that went through a long and wild transition, encountered after the ' $90 \mathrm{~s}$, certain social facts. It's not that this phenomenon that we are about to analyze did not exist, but they weren't talked publicly. The phenomenon are the divorce, abortion, euthanasia, prostitution, and homosexuality that don't necessarily connect to each other. It's normal that the divorce that was somehow legal, it's not treated in the same way as the abortion that was illegal or as homosexuality that was never discussed in the Albanian communist society. The purpose of the paper is not to treat this phenomenon as equal, but to observe them in the specter that in the communist times they were banned altogether.

The quantitative methodology of this paper tries to measure the public opinion concerning this issues so we could understand the differences between them and the general approach. First, we try to conceptualize the clear concept of the phenomenon and the background of the last 50 years of the communist regime on how the society understood them. Second, they are treated as phenomenon that exist in the Albanian society and not as social choices that might ask for another methodology. Third, we consult the empirical data that we retrieved from the questioner and we analyze their outcome.

\section{Methodology}

I used quantitative method with the purpose of understanding the actual situation of the Albanian society. I have applied a questionnaire with structural question where the responders had to choose one of the given alternatives. This simplify the classification of data and common results. The survey took place only in Tirana, the capital of Albanian because we think that Tirana can be a representative of all the country. The reason is that according to last CENSUS of the country made by INSTAT (Statistical State Institute) in Tirana lives 1/3 of the population of our nation. (Census, 2012: 134) Secondly form a demographic point of view the internal migration during the democratic years in Tirana represents a conglomeration of different cultures from the regions where they have previously lived and lastly, Tirana is the only region that offers an easier infrastructure for mobility. 
These are the reasons that make me judge that by studding Tirana I will have the chance to generalize the result of the country without damaging the representativeness.

The survey was made by trained surveyors, which are students in the European University of Tirana. The surveyors did not complete by them self the survey and this avoided misunderstanding or fictitious fulfillment of the survey without even reading the questions. Instead, it assured that they wound answer the needs of the responders.

The quota sampling method was selected because there is a lack of accurate data and address of the population and also because this method preserves the proportions of population's age, gender, income, etc.

In order to understand the values in time, the sampling was divided in group age. Given that the number of Tirana's population was around 600,000 of people aged over 15 years, (Census, 2012:134) it was decided for the sampling size to be 250 responders.

The data were collected, reviewed and processed in the SPSS program which offers a better option for statistical analysis by using the frequency device to analyze the society profile

\section{Albanian communism and treatment of social phenomena}

According to Emile Durkheim (1951), suicide was considered as one of the most intensely individual acts, which are purely determined by biographical and psychological factors. Variations in suicide differ from one ethnic, religious, racial and occupational group to another. Durkheim believed that there is a relationship between society and self and this highly contributes to the spread of suicide. Suicide rates is an indication of the extend to which people are not included into the societies group of life (Durkheim, 1951).

During communism, killing was also an exclusivity of the state. If you decided to kill yourself you should think on the consequences that would fall on your family and relatives. This because in essence, to kill yourself meant to be upset to communism and not to yourself. According to the latest WHO data published in April 2011 Suicide Deaths in Albania reached 196 or $0.90 \%$ of total deaths. The age adjusted Death Rate in 2011 , is 6.11 per 100,000 of population ranks Albania \#116 in the world. (http://www.worldlifeexpectancy.com/albania-suicide) The age adjusted Death Rate is 5.9 per 100,000 of population ranks Albania in 2012. (http://apps.who.int/gho/data/view.main.MHSUICIDEv.) For 2013 and 2014 in Albania we have found interesting numbers from WHO, concerning the number of psychiatric medics. The number of psychiatrists per 100000 population ranges vary widely: from 30 per 100000 in Switzerland and 26 in Finland to 3 in Albania and 1 in Turkey. (http://www.euro.who.int/en/health-topics/noncommunicable-diseases/mental-health/data-andstatistics)

Euthanasia refers to the practice of ending a life in a painless manner, usually by lethal injection or withdrawing lifesupporting treatment. Assisted suicide differs to euthanasia as the doctor merely provides the means of committing suicide. The debate about whether people should be allowed to determine when they die is a complex and long running one. Euthanasia means "accelerated death of the person who suffers from an incurable disease, triggering fatal or serious physical abnormality, which aggravates the mental, emotional or physical state of the patient (terminal illness), and that can be caused in different ways and from different subjects, under the clear and continuous desire of the patient, with the only interest of giving an end to his sufferings"

According to the Professor Ismet Elezi "murder is an unlawful act or omission, through which another person is deprived of life intentionally or recklessly" . Euthanasia differs very little from the murder described above, to not say that it doesn't differ at all. Both concepts consist of taking away another person's life (Elezi, Kacupi, Haxhia, 2001:235).

Regarding the divorce in Albania, after adoption of the constitution of 1946, new laws were implemented regulating marriage and divorce. Marriages had to be contracted before an official of the local People's Council. After 1967, religious wedding ceremonies were forbidden. The minimum age for marriage was set at sixteen for women and eighteen for men. Because marriage was now supposed to be based on the full equality of both spouses, the concept of the father as head of the family, recognized by precommunist civil law and considered essential to Albanian family life, was officially deprived of legitimacy. A husband and wife now had the legal right to choose their own residence and professions. However, marriage to foreigners was prohibited except with the permission of the government.

The new divorce laws were designed to facilitate proceedings. The separation of spouses was made grounds for divorce, and in such cases a court could grant a divorce without considering related facts or the causes of the separation. Either 
spouse could ask for a divorce on the basis of incompatibility of character, continued misunderstandings, irreconcilable hostility, or for any other reason that disrupted marital relations to the point where cohabitation had become intolerable. Certain crimes committed by the spouse, especially so-called crimes against the state and crimes involving moral turpitude, were also recognized as grounds for divorce. In divorce cases, custody of children was granted to the parent "with better moral and political conditions for the children's proper education."

Furthermore, until 1991, abortions were illegal and women were encouraged to have "as many children as possible," in addition to working outside the home. Some traditional practices, such as the presentation of dowries and arranged marriages, reportedly were condoned by the authorities.

Throughout its existence, the communist regime persisted in its campaign against the patriarchal family system. In the mountainous north, where vestiges of traditional tribal structures were particularly prevalent, the local patriarchs were detained and the property of their clans was appropriated. Patriarchalism, according to party propaganda, was the most dangerous internal challenge to Albanian society.

Homosexuality carried harsh penalties in the People's Socialist Republic of Albania, to which convicted homosexuals faced lengthy prison sentences and ill-treatment in prison. Prostitution was another unknown phenomenon during communism, as wellas a social taboo. Due to the social ostracism that prostitutes are subjected to, generally, the entry of a member into prostitution provokes downward spiraldeeper into poverty for a family (Sokoli, Gedeshi, 2006). In the study that Natalia Ribas Mateos makes, she mentioned that "Albanians often mention the fact that nowdays gypsy women tend to be the prostitutes in Albania, and that they also were in the past when prostitution was forbidden during communism." (Ribas Mateo, 2005:331)

\section{Empirical study}

The questioner, contained more issues than the ones that we elaborated. Based on the religious teachings and principles, Inglehart makes a classification of the position that people will take on such phenomenon as: abortion, divorce, euthanasia, and suicide. He connects it to their pillar of values whether they are traditional believers or seculars. This phenomenon are banned by the religious institutions and from the Great Will of the God that they believe. So, we also put this phenomenon to the questioned, in a list of things that they might encounter in their life. This, in order for them to give a mark if they never justify an action as such, (which we noted as 1 , in a scale of 10 , where by 10 was noted if they always justify this action). The answers marked from 1 to 4 are classified as completely in the traditional values side and the answers given from 7 to 10 are classified as completely on the side of the secular values. Let's take a look at each and every one of the phenomenon, given that their perception differs from the next.

The first in the list is abortion, to which $70.9 \%$ of the questioned answered on the side of the traditional values pillar. From this group, $48.5 \%$ of them answered that this is never justified (which corresponded to our mark of 1 ). Meanwhile $16.1 \%$ of the questioned answered on the side of the secular values. The expectations over this question where for the secular values to receive more marks, this because the Albanian law allows abortion under some certain specifications (yet it allows it). And this could have influenced the people to justify this action even more. Anyway this did not happen. Which gives us a clear indicator that values are not essentially related to what the law allows or not in a society. For more specification over the answering results the table below helps us:

$\begin{array}{lllllllllllll}\begin{array}{l}\text { Justification } \\ \text { on abortion }\end{array} & \begin{array}{l}1 \\ \text { (Never) }\end{array} & 2 & 3 & 4 & 5 & 6 & 7 & 8 & 9 & 10 \text { (always) } & \begin{array}{l}\text { don't } \\ \text { know }\end{array} & \begin{array}{l}\text { No } \\ \text { answer }\end{array} \\ \text { Percentage } & 48.5 & 8 . & 8 . & 5 . & 9 . & 3 . & 6.3 & 3.0 & 1 . & 5.1 & 0 & 0.4 \\ & & 0 & 9 & 5 & 3 & 4 & & & 7 & & & \end{array}$

The next phenomenon is the divorce. To which the questioned answered in $46.4 \%$ on the side of the traditional values and $31.4 \%$ on the side of the secular values. Here, as it looks, the fact that the divorce has always been accepted by the law as an opportunity that is given to the married couples in case that the contradictions that they might have cannot be solved through mutual understanding, has influenced the result. This is the aspect which $i$ think influenced, even though this is a society more and more opened on the different forms of being in a couple. The table below shows the concrete results: 


\begin{tabular}{|c|c|c|c|c|c|c|c|c|c|c|c|c|}
\hline \multicolumn{3}{|c|}{$\begin{array}{l}\text { ISSN 2411-9563 (Print) } \\
\text { ISSN 2312-8429 (Online) }\end{array}$} & \multicolumn{7}{|c|}{$\begin{array}{c}\text { European Journal of Social Sciences } \\
\text { Education and Research }\end{array}$} & \multicolumn{3}{|c|}{$\begin{array}{l}\text { January-April } 2015 \\
\text { Volume 2, Issue } 1\end{array}$} \\
\hline $\begin{array}{l}\text { Istifying } \\
\text { vorce }\end{array}$ & $\begin{array}{l}1 \\
\text { (never) }\end{array}$ & 2 & 3 & 4 & 5 & 6 & 7 & 8 & 9 & $\begin{array}{l}10 \\
\text { (always) }\end{array}$ & $\begin{array}{l}\text { Don't } \\
\text { know }\end{array}$ & $\begin{array}{l}\text { No } \\
\text { answer }\end{array}$ \\
\hline ercentage & 27.4 & 7.2 & 3.8 & 8.0 & 16.5 & 5.5 & 8.0 & 7.6 & 5.9 & 9.7 & 0.4 & 0 \\
\hline
\end{tabular}

The next phenomenon questioned is euthanasia, in which, several times the clarification of the word was needed. This because in our country the phenomenon is not discussed enough maybe because we did not have many health cases as such into which, the public opinion was called in judgment, as it happened in the countries nearby. In this question, $71.6 \%$ answered on the side of the traditional values, and $15.7 \%$ on the side of the secular values. For more, the following table:

$\begin{array}{lllllllllllll}\begin{array}{l}\text { Justifying } \\ \text { euthanasia }\end{array} & \begin{array}{l}1 \\ \text { (never) }\end{array} & 2 & 3 & 4 & 5 & 6 & 7 & 8 & 9 & \begin{array}{l}10 \\ \text { (always) }\end{array} & \begin{array}{l}\text { Don't } \\ \text { know }\end{array} & \begin{array}{l}\text { No } \\ \text { answer }\end{array} \\ \text { Percentage } & 56.8 & 7.2 & 5.9 & 1.7 & 3.8 & 2.5 & 4.7 & 3.8 & 1.7 & 5.5 & 4.7 & 1.7\end{array}$

The last phenomenon is suicide, which is a known phenomenon for our society and that has been analyzed a lot in the mass media. The questioned answered $93.7 \%$ on the side of the traditional values and from this group, $83.9 \%$ stand for never justified. On the side of the secular values, only $1.5 \%$ of the questioned. This extreme percentage is thought to be related to the belief that life is a gift from God and goes along with the indicator questioned prior, where God results as an important part of their life. By giving this much importance to God, a stance like this was expected.

$\begin{array}{lllllllllllll}\begin{array}{l}\text { Justifying } \\ \text { suicide }\end{array} & \begin{array}{l}1 \\ \text { (never) }\end{array} & 2 & 3 & 4 & 5 & 6 & 7 & 8 & 9 & \begin{array}{l}10 \\ \text { (always) }\end{array} & \begin{array}{l}\text { Don't } \\ \text { know }\end{array} & \begin{array}{l}\text { No } \\ \text { answer }\end{array} \\ \text { Percentage } & 83.9 & 3.8 & 4.7 & 1.3 & 2.5 & 0 & 0.4 & 1.3 & 0 & 0.8 & 0.8 & 0.4\end{array}$

The next question was: "For each of the phenomenon below, can you tell us if you always justify it?"
a) Homosexuality
b) Prostitution

If the questioned answer from 1 to 4 , thus by not justifying the phenomenon, then they belong to the values of survival. If they mark from 7 to 10 , by justifying them, then they belong to the values of self-fulfillment.

Concerning homosexuality, $74.3 \%$ of the questioned marked it with 1 , as never justified. By giving a strong majority of the mark one on the side of the values of survival. Adding here also the other marks on the same side, the percentage goes to $85.3 \%$. On the other side, the side of the values of self-fulfillment are only $5.5 \%$ with only $1.3 \%$ as always justifying it. The table gives us the varied results:

\begin{tabular}{|l|l|l|l|l|l|l|l|l|l|l|l|l|}
\hline $\begin{array}{l}\text { Justifying } \\
\text { homosexuality }\end{array}$ & 1 & 2 & 3 & 4 & 5 & 6 & 7 & 8 & 9 & 10 & $\begin{array}{l}\text { Don't } \\
\text { know }\end{array}$ & $\begin{array}{l}\text { No } \\
\text { answer }\end{array}$ \\
\hline Percentage & 74.3 & 5.5 & 3.4 & 2.1 & 6.3 & 0.8 & 1.3 & 2.5 & 0.4 & 1.3 & 0.8 & 1.3 \\
\hline
\end{tabular}

The next point was prostitution. To this, the questioned, again answered on the side of the survival values by giving the mark 1 on $77.6 \%$ of the times, and $89.8 \%$ added to the other marks of the same side. Meanwhile, on the side of the values of self-fulfillment, the questioned that justify this phenomenon are only $2 \%$. And we have to stress, that none of the questioned marked 10. For more, the table below:

\begin{tabular}{|l|l|l|l|l|l|l|l|l|l|l|l|l|}
\hline $\begin{array}{l}\text { Justifying } \\
\text { prostitution }\end{array}$ & 1 & 2 & 3 & 4 & 5 & 6 & 7 & 8 & 9 & 10 & $\begin{array}{l}\text { Don't } \\
\text { know }\end{array}$ & $\begin{array}{l}\text { No } \\
\text { answer }\end{array}$ \\
\hline Percentage & 77.6 & 5.9 & 3.8 & 2.5 & 4.6 & 1.7 & 0.8 & 0.8 & 0.4 & 0 & 1.3 & 0.4 \\
\hline
\end{tabular}


Concerning prostitution and homosexuality, in order to understand better, we chose not to question related merely to the justification or not of the phenomenon, but also of the persons. Which means the judgment on the prostitutes and the homosexuals, as how would they accept these people near them. The question asked was: "I will give you a list of people of different categories. Can you tell us if among them you find people that you do not wish to have as your neighbors? Which ones?" Options: I do not want them (1); I want them (2); Indifferent (88); No answer (99). Concerning prostitutes, the table below reveals us that a majority of $77.1 \%$ does not wish to have them as neighbors, which means that they do not accept to have them near, and nor to have everyday visual contact to the prostitutes.

\begin{tabular}{|l|l|l|l|l|}
\hline Prostitutes & Do not want them & I want them & Indifferent & No answer \\
\hline Percentage & 77.1 & 13.5 & 9.0 & 0.4 \\
\hline
\end{tabular}

Almost the same results came out concerning the issue of homosexuals where the questioned answered that they would not want them as neighbors on the score of $78.3 \%$. Giving hereby again their no acceptance over the phenomenon but also for the homosexuals as persons. The table below gives us the exact percentage of each option:

\begin{tabular}{|l|l|l|l|l|}
\hline Homosexual & Don't want them & I want them & Indifferent & No answer \\
\hline Percentage & 78.3 & 10.7 & 10.2 & 0.8 \\
\hline
\end{tabular}

\section{Conclusion}

In this paper were taken in consideration some social phenomena encountered today in Albanian society but not only. These phenomena were treated together for the fact that during the communist period were not issues for the public and for the judgment of the people. Phenomena were divorce, abortion, suicide, euthanasia, prostitution and homosexuality as different to each other. From the historical content we realized that the phenomena were treated in a different way during the communist period. Divorce, from all the phenomena was legally allowed/permitted. Even though, in practice the communist moral do not accept it and after this the punishment takes different forms. Abortion was illegally but in different circumstances was rarely permitted. Another phenomenon, prostitution was also illegally but it was not denied in Albania and the regimen played the role of the "ignoramus". The suicide was specific as a phenomena and it was not expected to have a legal adjustment. Even though every society does not support the suicide, during the communism if a member of a family commit a suicide his/her family was persecuted. Homosexuality was legally punished during the communist period and the identified persons was obliged to take hormonal medicines. While euthanasia was never discussed as a phenomena of the society.

The results taken from the survey show that:

Divorce justification was $46.4 \%$

Abortion justification was $70.9 \%$

Suicide justification was $1.5 \%$

Euthanasia justification was $15.7 \%$

Prostitution justification was $2 \%$

Homosexuality justification was $5.5 \%$

As above, Albanians stand in the side of the traditional values instead of centuries values. Being different from other phenomena where every person is object in a specific moment, prostitution and homosexuality are connected with the daily life and with assigned persons, not only a phenomena. From the survey also it comes out that persons were not accepted at $75 \%$, again in the side of traditional values.

The higher scale of unacceptance is connected with the less known and discussed phenomena during the communism period in Albania. I believe that there is a connection between recognition and acceptance as showed even from the data. In this way, if the society need is to be opened towards the phenomena than the recognition is the key for the acceptance. Today in a global world where these phenomena are more than discussed, it is needed to enlarge the discussion also for the Albanian public opinion. 


\section{Bibliography}

[1] Damousi, J., Plotkin, M. B. (2012) "Psychoanalysis and Politics: Histories of Psychoanalysis Under Conditions of Restricted Political Freedom" Oxford University Press: USA

[2] Durkheim, E. (1951) Suicide : a study in sociology. The Free Press

[3] Elezi, I., Kaçupi, S., Haxhia, M. (2001) "Commentary of the Criminal Code of the Republic of Albania", Tirana

[4] Inglehart, R. \& Baker, E.W, (2000) "Modernization, cultural change and the persistence of traditional values" American Sociological Review, Vol. 65 (February:19-51)

[5] Population and Housing Census of Albania 2011 (2012) INSTAT ALBANIA, Tirana: Adel Print.

[6] Ribas, M. (2005) "The Mediterranean In The Age Of Globalization: Migration, Welfare, And Borders", Transaction Publishers:New Jersey

[7] Sokoli, L., Gedeshi, I. (2006) "Trafikimi, Rasti i Shqiperise”. Instituti i Sociologjise: Tirane

[8] Internet source

[9] From http://www.worldlifeexpectancy.com/albania-suicide last seen january 2015.

[10] From http://apps.who.int/gho/data/view.main.MHSUICIDEv last seen january 2015.

[11] From http://www.euro.who.int/en/health-topics/noncommunicable-diseases/mental-health/data-and-statistics last seen january 2015. 